\title{
Wymagania w zakresie spawania pojazdów szynowych w aspekcie obowiązujących norm i przepisów.
}

\begin{abstract}
$W$ artykule przedstawiono wymagania zawarte $w$ seriach norm $w$ zakresie spawania obowiqzujacych przy budowie i naprawie pojazdów szynowych. Ponadto przedstawiono wymagania określone przez konstruktora na etapie projektowania pojazdu dotyczqce technologii wykonania oraz jakości połaczeń spawanych. Omówiono zasady przedstawiania połaczeń spawanych na rysunkach. Opisano również zagadnienie uszkodzenia spoin. Ponadto zaprezentowano przyklady metod spawania metali.
\end{abstract}

\section{WPROWADZENIE}

Ustroje nośne (ramy, ostoje, belki nadwózkowe) pojazdów szynowych są poddawane oddziaływaniom zmiennym związanym $\mathrm{z}$ charakterem pracy pojazdu przez co narażone są na zjawisko zmęczenia. W celu zabezpieczenia tych konstrukcji przed zjawiskiem pęknięcia zmęczeniowego należy je projektować $\mathrm{z}$ uwzględnieniem wytycznych zawartych w odpowiednich normach oraz z uwzględnieniem wymagań określonych przez konstruktora zawartych w dokumentacji konstrukcyjnej.

$\mathrm{Na}$ proces inicjacji i propagacji pęknięć zmęczeniowych wpływa bardzo wiele różnych czynników. W przypadku spawania najważniejsze są:

- naprężenia pozostające po spawaniu

- niezgodności spawalnicze

- kształty spoiny

- skład i własności mechaniczne materiału rodzimego

- szerokość i grubość łączonych elementów

- sposób przygotowania brzegów

- proces spawania

- pozycja spawania

- obróbka mechaniczna po spawaniu

- obróbka cieplna po spawaniu.

W obowiązujących w Polsce normach istnieje szereg przepisów, związanych z prawidłowym projektowaniem i wykonywaniem połączeń spawanych $\mathrm{w}$ pojazdach szynowych, obejmujących powyższe zagadnienia.

2. WYMAGANIA W ZAKRESIE SPAWANIA CZECŚCI SKŁADOWYCH POJAZDÓW SZYNOWYCH

\subsection{Seria norm EN 15085}

\subsubsection{EN 15085-1 [2]}

W części pierwszej zawarto ogólne zalecenia i definicje odnoszące się do produkcji spawalniczej pojazdów szynowych i związanych z nimi komponentów. Zgodnie z [4] klient nie narzuca wytwórcy tech- nologii wykonania wyrobu a jedynie określa wymagania eksploatacyjne. Zatem wytwórca posiada swobodę wyboru procesu spawania wraz ze wszystkimi czynnościami około spawalniczymi.

Ważnym zapisem [4] jest również to, że wytwórca musi wykazać potencjalnemu klientowi, że dysponuje kompleksową kontrolą jakości oraz że żądane prze klienta wymagania jakości będą uzyskane szczególnie przez:

- certyfikację wytwórcy

- kwalifikowanie spawaczy i operatorów/ nastawiaczy

- kwalifikowanie procesów spawania i próby robocze.

\subsubsection{EN 15085-2 [5]}

Ta część normy określa poziom certyfikacji, jak również wymagania w stosunku do zakładu spawalniczego. Ponadto zawiera opis procedury kwalifikowania zakładów spawalniczych. Zgodnie z [5] rozróżniamy następujące poziomy certyfikacji: CL1, CL2, CL3, CL4.

Zgodnie z [5] następujące elementy mogą być wytwarzane tylko w zakładach spawalniczych certyfikowanych dla poziomu certyfikacji CL1:

- wózki (czołownica, ostojnica, belka skrętowa, rama wózka)

- podwozie (część czołowa ostoi, ostojnica i belka skrętowa, montaż)

- nadwozie pojazdu szynowego (ściany czołowe, ściany boczne, dach)

- urządzenia cięgłowo zderzakowe

- ramy nośne dla zewnętrznych elementów wyposażenia

- mocowanie zestawu kołowego, łożyska osiowe, wsporniki amortyzatorów drgań, amortyzatory, amortyzatory drgań 
- osprzęt hamulca (magnetyczny hamulec szynowy, cięgła, trójkąty hamulcowe, cylindry hamulcowe, belki hamulcowe)

- ramy nośne do bardzo ciężkich pojazdów

- cześci przyspawane służące do przeniesienia siły pociagowej z wózka na pojazd szynowy

- zbiorniki paliwa pojazdów szynowych

- spawanie produkcyjne odlewów w ramach wyżej wymienionych elementów konstrukcyjnych

- zbiorniki gazu sprężonego, cysterny i kontenery cysterny pojazdów szynowych poddawane próbom ciśnieniowym.

Dla poziomu certyfikacji CL1 lub CL2 (w zależności od klasy jakości spoin) sklasyfikowano m.in. następujące elementy :

- drzwi wejściowe do wagonu

- elementy przeniesienia napędu

- ściany przesuwne w pojeździe

- uchwyty do przewodów hamulcowych

- wyposażenie kabiny maszynisty.

Poziom certyfikacji CL3 obowiązuje przy wykonywaniu lub naprawianiu m.in.:

- korb i dźwigni różnego przeznaczenia

- klinów do podstawiania pod koła pojazdu

- ram siedzeń

- ram okiennych.

Ostatni poziom certyfikacji CL4 obejmuje zakład, który nie utrzymuje własnej produkcji spawalniczej ale konstruuje lub kupuje i montuje spawane komponenty i elementy konstrukcyjne.

\subsubsection{EN 15085-3 [6]}

W tej części serii norm zawarto wytyczne konstruowania i klasyfikacji do budowy i obsługi technicznej pojazdów szynowych i ich elementów konstrukcyjnych.

Przy projektowaniu połączeń spawanych wchodzących w skład pojazdów szynowych, spełnione muszą być poniższe wymagania o ile $\mathrm{w}$ ramach danego projektu lub specyfikacji wyrobu nie dokonano innych ustaleń:

\section{a. wytrzymałość statyczna}

Obliczone naprężenia muszą być mniejsze lub równe od wartości dopuszczalnych dla rozpatrywanych komponentów, które podane są w specyfikacji lub przez wytwórcę i zaakceptowane przez uzgodnioną jednostkę.

\section{b. wytrzymałość zmęczeniowa}

Projektowanie połączeń spawanych powinno odbywać się odpowiednio do istniejącego stanu naprężeń i kategorii bezpieczeństwa. Dopuszczalne parametry wytrzymałości zmęczeniowej, które określone są w normach, przepisach, procedurach, wytycznych lub na wykresach wytrzymałości zmęczeniowej, zamieszczane są w specyfikacji lub przez wytwórcę i muszą być zaakceptowane przez uzgodnioną jednostkę lub kompetentny krajowy urząd bezpieczeństwa.

\section{c. stan naprężeń i współczynnik naprężeń}

Stan naprężeń określany jest przez współczynnik naprężeń, który to jest wyrażany stosunkiem naprężenia rzeczywistego do naprężenia dopuszczalnego dla obliczonego typu złącza przy uwzględnieniu właściwego współczynnika bezpieczeństwa.

Norma lub źródło, z którego wybiera się dopuszczalne wartości naprężeń powinny być ustalone między klientem a wytwórcą i ewentualnie krajowym urzędem bezpieczeństwa. Należy przy tym uwzględnić wymagania zawarte w odpowiednich normach.

\section{d. kategoria bezpieczeństwa}

Kategoria bezpieczeństwa definiuje skutki uszkodzenia pojedynczej spoiny w odniesieniu do następstw wywieranych na ludzi, urządzenia i środowisko. Podział kategorii zawarto w tabeli 1.

\section{e. klasy jakości spoin}

Klasy jakości spoin określane są $\mathrm{w}$ fazie projektowania $\mathrm{W}$ zależności od kategorii bezpieczeństwa $\mathrm{i}$ stanu naprężeń. Należy konsultować się z odpowiednim nadzorem spawalniczym odnośnie praktycznych możliwości wykonania. W tabeli 2 przedstawiono klasy jakości.

Tabela 1 Kategorie bezpieczeństwa spoin [6]

\begin{tabular}{l|l}
\hline Kategoria & Opis \\
\hline Niska & $\begin{array}{l}\text { Uszkodzenie spoiny nie prowadzi do bezpośredniego naruszenia funkcjonalności. } \\
\text { Wynikające stąd zdarzenia zagrażające życiu i zdrowiu osób są nieprawdopodobne }\end{array}$ \\
\hline Średnia & $\begin{array}{l}\text { Uszkodzenie spoiny prowadzi do bezpośredniego naruszenia funkcjonalności i może } \\
\text { prowadzić do wynikających stąd zdarzeń zagrażających życiu lub zdrowiu osób }\end{array}$ \\
\hline Wysoka & $\begin{array}{l}\text { Uszkodzenie spoiny prowadzi do wynikających stąd zdarzeń zagrażających życiu lub } \\
\text { zdrowiu osób i do utraty funkcjonalności }\end{array}$ \\
\hline
\end{tabular}

Tabela 2

Klasy jakości spoin [6]

\begin{tabular}{c|c|c|c}
\hline \multirow{2}{*}{ Stan naprężeń } & \multicolumn{3}{|c}{ Kategoria bezpieczeństwa } \\
\cline { 2 - 4 } & Wysoka & Średnia $^{\text {Naska }}$ \\
\hline Wysoki & CP A $^{\mathrm{a}}$ & CP C2 & CP C2 \\
\hline Średni & CP B $^{\mathrm{b}}$ & CP C3 3 \\
\hline Niski & CP C1 $^{\mathrm{d}}$ & CP D \\
\hline
\end{tabular}




\begin{abstract}
${ }^{a}$ Klasa jakości Spoiny CP A jest specjalnq klasq jakości spoin, która obowiqzuje tylko dla spoin wykonanych z petnym przetopem $i$ w petni dostępnych do przeprowadzenia kontroli i badań $w$ trakcie produkcji i obstugi technicznej

${ }^{b}$ CP B dla kategorii bezpieczeństwa ,wysoka” obowiazuje tylko dla spoin wykonanych z petnym przetopem $i$ w petni dostępnych do przeprowadzenia kontroli i badań w trakcie produkcji i obstugi technicznej

${ }^{c}$ CP B dla kategorii bezpieczeństwa „średnia” jest dopuszczalna również dla spoin bez możliwości wykonania badań objętościowych; $w$ takim przypadku konieczne jest umieszczenie na rysunku specjalnej wskazówki ,średnia kategoria bezpieczeństwa/ konieczne rozszerzone badania na wykrywanie pęknięć powierzchniowych'i trzeba przeprowadzić badania zgodnie z odpowiednimi wytycznymi zawartymi w normie [7].

${ }^{d}$ CP Cl jest również dopuszczalna dla spoin bez możliwości wykonania badań objętościowych. W takim przypadku konieczne jest umieszczenie na rysunku specjalnej wskazówki , konieczne badania na wykrywanie pęknięć powierzchniowych” i trzeba przeprowadzić badania zgodnie z norma [7]
\end{abstract}

Klasy jakości spoin określane są w fazie projektowania w zależności od kategorii bezpieczeństwa i stanu naprężeń. Należy konsultować się z odpowiednim nadzorem spawalniczym odnośnie praktycznych możliwości wykonania. W tabeli 2 przedstawiono klasy jakości.

\section{f. klasy badania spoin}

Do każdej klasy jakości spoiny przypisana jest klasa badania spoiny celem łatwej identyfikacji rodzaju i wymaganego minimalnego poziomu badań danej spoiny. Zgodnie z normą [7] rozróżniamy następujące klasy badania spoiny: CT 1, CT 2, CT 3, CT 4.

Ponadto w normie [6] podano wytyczne dla doboru materiałów podstawowych i materiałów dodatkowych do spawania - materiał podstawowy musi spełniać wymagania określonych wg CEN ISO/TR 15608 grup materiałowych oraz posiadać odpowiednią wrażliwość na spajanie.

Kolejnym, ważnym zagadnieniem zawartym w normie [6] są wytyczne dla projektowania złączy spawanych. Przy projektowaniu należy m.in:

- unikać połączeń spawanych o ostrych narożach i nagłych zmianach przekroju - linie przebiegu sił powinny być niezakłócone

- unikać usytuowania spoin w obszarze o wysokich naprężeniach

- dla uzyskania rozstrzygnięcia w fazie projektowania może być konieczne wykazanie obliczeniowej grubości spoiny przez wykonanie prób roboczych

- zabezpieczyć połączenie spawane przed korozja np. przez zastosowanie spawu z pełnym przetopem. Jeśli nie jest możliwe uzyskanie takiego typu połączenia lub tez stosowane są spoiny przerywane należy wówczas zastosować inny typ ochrony przed korozją

- tak konstruować zespoły aby zapewniony był dostęp do spawania i przeprowadzania kontroli

- unikać koncentracji spoin i w miejscach w których występują rozważyć stosowanie elementów kutych lub odlewanych

- unikać połączeń mieszanych w których występują złącza spawane i np. śrubowe lub nitowane.

W kolejnym punkcie normy [6] zawarto przepisy dotyczace wytwarzania konstrukcji spawanych odnoszące się do: a. konstrukcji belek skrzynkowych - wymagania w zakresie stosowania typów spoin w zależności od obciążenia konstrukcji

b. spoin czołowych w elementach konstrukcyjnych o różnej grubości - wymagania wymiarowe w zakresie spawania elementów o różnej grubości

c. spoin otworowych i spoin w otworach podłużnych - wymagania wymiarowe w zakresie wykonywania spoin otworowych i spawania w otworach podłużnych

d. odległości między spoinami - wymagania wymiarowe odnośnie minimalnych odległości między kolejnymi spoinami

e. krzyżowania się spoin czolowych i pachwinowych

f. wykroi otwartych - wymagania w zakresie stosowania otworów w elementach spawanych

g. zakończenia wsporników i usztywnień - wymagania wymiarowe $w$ zakresie projektowania wsporników w obszarach łączenia z pozostałymi elementami

h. kształtu wsporników - wymagania wymiarowe w zakresie kształtu elementów poddawanych obciążeniom dynamicznym

i. wymagań do stosowania spoin pachwinowych oraz spoin czołowych

j. zlącz spawanych utwierdzonych

k. połączeń mieszanych - wymagania $\mathrm{w}$ zakresie stosowania połączeń mieszanych np. spawanie i skręcanie

l. korozji połączeń spawanych

m. przejścia spoiny w materiał podstawowy - wymaganie w zakresie obróbki mechanicznej poprawiającej parametry wytrzymałościowe spoin

n. zmniejszenia naprężeń własnych - opis operacji technologicznych poprawiających własności

złącz spawanych

Ponadto w normie [6] przedstawiono wymagania w zakresie przygotowania brzegów do spawania oraz wymagania $\mathrm{w}$ zakresie prawidłowego znakowania spoin. Zgodnie z [6] na rysunkach powinny znajdować się następujące informacje:

- klasa jakości spoiny - jeśli jeden rysunek posiada różne klasy jakości spoin muszą być one podane obok spoiny 
- poziomy certyfikacji od CL 1 do CL 3 muszą być podane dla każdego elementu konstrukcyjnego na rysunku lub w wykazie częśc

- rodzaj, grubość i długość spoiny

- materiały dodatkowe do spawania - przy czym te informacje mogą być zawarte w wykazach części lub innych dokumentach.

\subsubsection{EN 15085-4 [7]}

W części 4 serii norm EN 15085 zawarto informacje odnośnie spawalniczego przygotowania produkcji, wymagań dotyczących spawania oraz spawalniczej naprawy pojazdów szynowych.

W zakres spawalniczego przygotowania produkcji wchodzą następujące czynności:

a) opracowanie spawalniczej dokumentacji

b) wykonywanie prób roboczych - celem wykonywania prób roboczych jest m.in. sprawdzenie i zapewnienie, że konstrukcja spełnia wymagania wyspecyfikowane w normie [6]; sprawdzenie procesu spawania; wykazanie kwalifikacji personelu spawalniczego; wykazanie jakości spoin

Ponadto w normie [7] zawarto wymagania techniczne w zakresie spawania pojazdów szynowych i ich elementów konstrukcyjnych odnoszące się do:

a) przygotowania brzegów do spawania - przygotowanie brzegów należy wykonać zgodnie $\mathrm{z}$ wymaganiami zawartymi $\mathrm{w}$ dokumentacji konstrukcyjnej oraz normie [6]

b) spawania - określono m.in. wymagania w zakresie spawania warstwowego spoin, kolejności układania ściegów, stosowania przyrządów spawalniczych, zapewnienia odpowiedniego środowiska pracy itd.

c) jakości spoin - do najważniejszych wymagań zawartych w tym punkcie należą:

- w przypadku usuwania karbów za pomocą dodatkowej obróbki (np. karby po szlifowaniu, rowki) grubość ścianki pozostającej nie może zmniejszyć się poniżej 95\% nominalnej grubości ścianki

- jeśli ze względów konstrukcyjnych w dokumentacji konstrukcyjnej przewidziana jest obróbka lub szlifowanie nadlewu lica spoiny to po wykonaniu tej obróbki podtopienia, kratery lub inne zewnętrzne niezgodności spawalnicze mogą pozostać wtedy, jeśli mieszczą się w granicach wymagań jakości

- jeśli w dokumentacji konstrukcyjnej przewidziane jest oszlifowanie spoin ze względów wytrzymałościowych to spoina powinna być oszlifowana bez karbów w kierunku dzialania obciążenia

- do naprawy spoin powinny być stosowane tylko technologie kwalifikowane i odpowiednie dla klasy jakości spoiny

- zabrania się zaspawywania pęknięć.

Ponadto $\mathrm{w}$ normie przedstawiono specyfikę spawalniczej naprawy pojazdów szynowych. Zgodnie z powyższym naprawa spawalnicza obejmuje prace spawalnicze wykonywane $w$ ramach remontów, a nie modernizacji lub przebudowy. Podczas opracowywania dokumentacji konstrukcyjnej naprawy spawalniczej określić należy badania i dokumentację zgodnie $\mathrm{z}[6]$.

W przypadku naprawy pojedynczych wad, spoiny klasy $C P C 1$ i $C P$ B muszą być poddane badaniom w $100 \%$. Dla wszystkich spoin wymagane jest $100 \%$ badań wizualnych. Ponadto wszystkie badania nieniszczące należy dokumentować.

\subsubsection{EN 15085-5 [8]}

Ta część serii norm EN 15085:

- definiuje kontrolę i badania jakim mają być poddane spoiny

- określa przeprowadzenie badań niszczących i nieniszczących

- definiuje dokumentowanie wymagane do wykonania i deklaracji zgodności wyrobu.

Do najważniejszych ustaleń i wymagań zawartych w niniejszej normie należy zaliczyć:

- wymagania w zakresie przeprowadzania kontroli i badań po spawaniu

- wymagania w zakresie wykonywania planu badań - dla każdego spawanego zespołu lub podzespołu zgodnie z planem badań w każdej chwili musi być widoczny aktualny status badań, które wymagane są dla spełnienia wymagań jakości zgodnie z [6]

- przeprowadzanie działań korygujących w przypadku wykrycia niezgodności spawalniczych

- wymagania w zakresie wykonywania prac spawalniczych na zasadzie podwykonawstwa.

\subsection{Wymagania zawarte w dokumentacji kon- strukcyjnej}

Projektując element konstrukcyjny pojazdu szynowego konstruktor ustala szereg wymagań odnoszących się do elementów spawanych i obejmujących zagadnienia wykonawstwa samych części jak i uwag odnośnie technologii wykonania.

Wymagania zawarte są na rysunkach konstrukcyjnych oraz w dokumentach przywołanych m.in. w Warunkach Technicznych Wykonania i Odbioru (WTWiO). W WTWiO umieszczono zagadnienia odnoszące się do:

- wymagań dotyczących zakładu spawalniczego zakład spawalniczy musi dysponować odpowiednim wyposażeniem technicznym wg EN ISO 3834 oraz powinien posiadać poziom certyfikacji wg [5]

- przygotowania części do spawania - części przeznaczone do spawania powinny być uprzednio wyprostowane, dopasowane $\mathrm{z}$ uwzględnieniem skurczu spawalniczego. 
- prac spawalniczych - technologia spawania, przyjęta przez wytwórcę, powinna zapewnić uzyskanie wymaganej w dokumentacji jakości złącz spawanych oraz dotrzymania tolerancji wymiarowych

- wykonywania i naprawy złącz spawanych

- kontroli jakości prac spawalniczych - kontrole jakości prac spawalniczych należy prowadzić $\mathrm{w}$ czasie całego procesu spawalniczego tj. podczas przygotowania do spawania, $w$ trakcie spawania oraz po zakończeniu spawania

- kontroli podczas przygotowania do spawania oraz podczas samego procesu spawania

- kontroli po spawaniu - po zakończeniu spawania należy przeprowadzić badanie wizualne wszystkich połączeń spawanych. Dla szczególnie ważnych złączy spawanych należy przeprowadzić dodatkowe badania NDT $\mathrm{w}$ ustalonym zakresie. W przypadku stwierdzenia wykonania nieprawidłowości wykonania spoin lub wykrycia niezgodności z dokumentacją należy usunąc wszystkie dostrzeżone usterki pod nadzorem Działu Kontroli Jakości producenta.

W wielu przypadkach konstruktor dodatkowo umieszcza wymagania konstrukcyjne odnośnie kształtu, badań czy też jakości wykonania spoin na rysunkach. Poniżej podano przykłady takich wymagań.
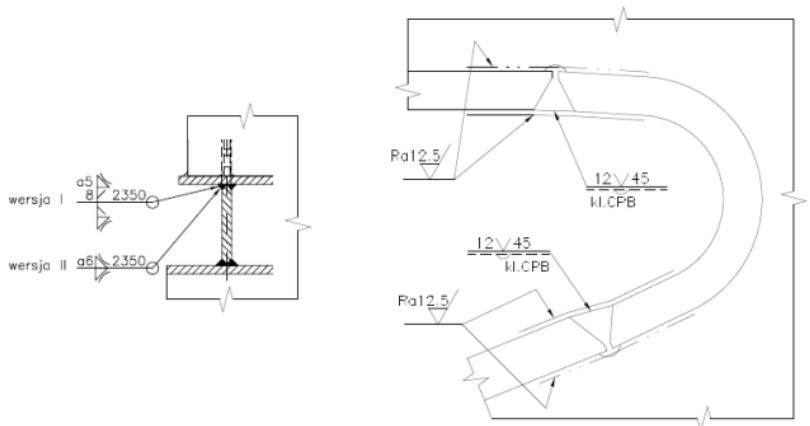

Dopuszcza sie rownież wykonanie zamiast spoin pachwinowych z wklestym licem "a... $\Delta$....." spoin pachwinowych z płaskim licem i tagodnym przejściem do metalu rodzimego "a... $\triangle$....".

Rys. 1 Przykład wymagań określonych w dokumentacji konstrukcyjnej

Oznakowanie przedstawione na rys.1 dotyczy wymagań odnośnie kształtu, klasy jakości oraz obróbki spoin używanych do łączenia elementów konstrukcyjnych ustroju nośnego pojazdu szynowego. Dla spoin pachwinowych wymagane jest wykonanie ich albo $\mathrm{z}$ wklęsłym licem albo $\mathrm{z}$ łagodnym przejściem $\mathrm{w}$ materiał rodzimy. W przypadku spoin czołowych konstruktor wymaga wykonania ich w odpowiedniej klasie jakości wykonania. Ponadto dla spoin czołowych przewidziano obróbkę mechaniczną celem poprawienia własności wytrzymałościowych złącza.

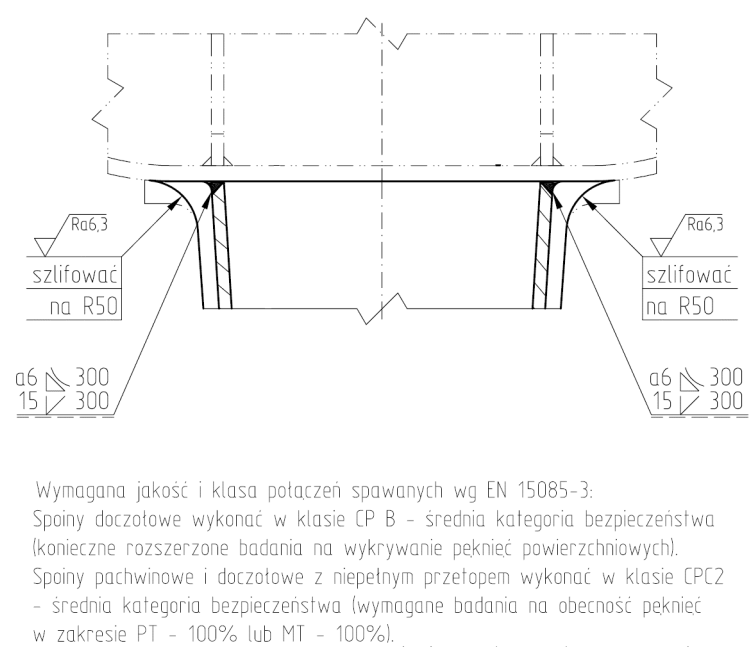

Rys. 2 Przykład wymagań określonych w dokumentacji konstrukcyjnej

Na rys 2 przedstawiono kolejny przykład wymagań określonych w dokumentacji konstrukcyjnej. Zgodnie z tym konstruktor określił klasę jakości spoin zgodnie $\mathrm{z}$ normą [6] oraz wymagane badania uwzględniające dany typ spoiny. Ponadto zastosowano również konieczność wykonania spoin z wklęsłym licem. Przewidziano również obróbkę mechaniczną po spawaniu elementu.

\section{WLAŚCIWOŚC EKSPLOATACYJNE PO- LĄCZEŃ SPAWANYCH}

\subsection{Wytrzymałość statyczna połączeń spawanych}

Konstrukcja złącza decyduje o wytrzymałości połączenia, jego masie, odkształceniach spawalniczych, technologiczności, pracochłonności i kosztach wykonania oraz możliwości i metodach kontroli jakości [3].

W pojazdach szynowych najczęściej występują połączenia doczołowe oraz kątowe.

Spoiny czołowe bez wad poddane obciążeniu statycznemu mają wytrzymałość nie mniejszą niż wytrzymałość materiału podstawowego. Wynika to $\mathrm{z}$ ogólnie przyjętych zasad doboru materiałów dodatkowych (spoiw). Dobierając np., materiały dodatkowe do spawania stali konstrukcyjnych należy w pierwszej kolejności brać pod uwagę granicę plastyczności materiału spawanego i spoiwa. Wartość granicy plastyczności spoiwa z założenia nie powinna być mniejsza od granicy plastyczności materiału spawanego. Wyższa wartość granicy plastyczności jest konieczna wówczas, gdy spoina przenosi bezpośrednio takie samo obciążenie, jakie działa na łączone elementy tworzace złącze. Pewien nadmiar wytrzymałości jest zabezpieczeniem przed lokalnym odkształceniem plastycznym spoiny na skutek sumowania naprężeń własnych spawalniczych i eksploatacyjnych i na wypadek występowania wad w spoinie, zmniejszających jej wymiar. Pęknięcie na skutek obciążenia statycznego jest poprzedzone znacznym odkształceniem plastycznym i zachodzi przeważnie poza spoina, zwykle w materiale rodzimym [3]. 


\subsection{Wytrzymałość zmęczeniowa}

Zjawisko zmęczenia polega na postępującym niszczeniu materiału przez powstanie i rozwój pęknięć pod wpływem wielokrotnych, okresowo zmiennych, naprężeń wywołanych obciążeniami mechanicznymi lub cieplnymi [3].

Pękanie zmęczeniowe rozwija się przy naprężeniach mniejszych niż granica plastyczności materiału i bez zauważalnych odkształceń plastycznych. Niebezpiecznymi miejscami są zawsze różnego rodzaju karby geometryczne spiętrzające naprężenia. Złącza spawane ze względu na niedoskonałość ich geometrii i procesu spawania zawierają niezgodności (przyklejenia, podtopienia, braki przetopu, nadmiernie wysoki nadlew, żużle) będące źródłem takiego spiętrzenia naprężeń. Poddane obciążeniom zmiennym pękają zwykle w przejściu lica spoiny do materiału rodzimego. Powiązanie między karbem a powstawaniem i propagacja pękania jest zasadniczą kwestią zjawiska zmęczenia. Drugorzędną jest struktura metalu złącza zmieniona $\mathrm{w}$ trakcie procesu cieplnego spawania. Należy podkreślić negatywną rolę spawalniczych naprężeń rozciagających, które zdecydowanie obniżają wytrzymałość zmęczeniową złączy spawanych. Tak więc złącze spawane należy uważać za newralgiczny pod względem zmęczeniowym element konstrukcji [3].

Wytrzymałość zmęczeniową złączy spawanych można zwiększyć, łagodząc karb geometryczny i/lub wprowadzając $\mathrm{w}$ obszar karbu naprężenia ściskające. Złagodzenie karbu można osiagnąć poprzez poprawne projektowanie i wykonywanie złączy spawanych, szlifowanie, śrutowanie, młotkowanie lub przetapianie lica spoin, szczególnie przejścia od spoiny do materiału spawanego. W technikach związanych $\mathrm{z}$ wprowadzeniem lub zmianą naprężeń wykorzystuje się miejscowe nagrzewanie i ściskanie w okolicy karbu oraz przeciążania konstrukcji [3].

\subsection{Przykłady uszkodzenia spoin}

Jak wcześniej wspomniano technologia wykonania elementu spawanego musi być zgodna $\mathrm{z}$ dokumentacją konstrukcyjna, WTWiO oraz przywołanymi normami w zakresie:

- wykonania i obróbki spoin

- przygotowania brzegów do spawania

- zachowania tolerancji wymiarowych.

W niniejszym punkcie przedstawiono przykłady uszkodzeń połączeń spawanych wynikające $\mathrm{z}$ niestosowania wymagań określonych w odpowiednich normach, przepisach, dokumentach odnoszących się do danego wyrobu.

Na rys. 4 i 5 przedstawiono przykłady nieciągłości spoin powstałych $\mathrm{w}$ elemencie poddawanym badaniom zmęczeniowym.
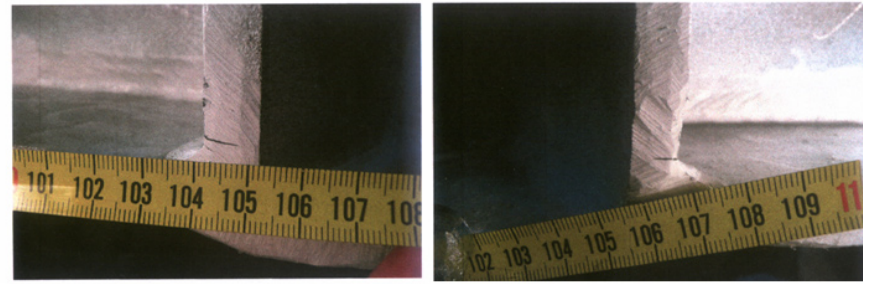

Rys. 4 Przykłady nieciagłość spoin (fot. A.Golonka)
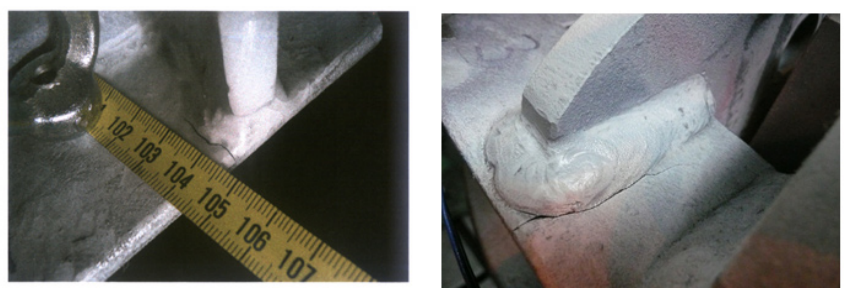

Rys. 5 Przykłady nieciagłość spoin (fot. A.Golonka)

Na rysunku 4 pokazano uszkodzenie spoiny wynikające $\mathrm{z}$ błędnie przeprowadzonej obróbki mechanicznej po spawaniu. Zgodnie z wymaganiami zawartymi w serii norm EN 15085 oraz w dokumentacji technicznej:

- ślady szlifowania powinny mieć kierunek wzdłuż krawędzi blachy

- nie powinny występować zacięcia i wgłębienia po tarczy szlifierskiej

- powierzchnie cięcia należy wykonać bez karbów i pęknięć

- w przypadku zastosowania płytek wybiegowych należy je usunać mechanicznie lub za pomocą cięcia tlenem lub plazmą. Powierzchnię cięcia należy oszlifować w kierunku wzdłużnym.

Rysunek 5 przedstawia przykład pęknięcia zmęczeniowego w którym prawdopodobną przyczyną uszkodzenia był nieodpowiedni kształt spoiny (zbyt wypukłe lico) i nieodpowiednia geometria przy przejściu do materiału rodzimego.

Określenie hierarchii oddziaływania parametrów geometrycznych jest trudne do wykonania. Jednakże na podstawie badań przeprowadzonych na połączeniu doczołowym jednostronnym (rys. 6), przy użyciu analizy wykorzystującej liniowo - sprężystą mechanikę pękania i metodę elementów skończonych określono kolejność - ważność parametrów geometrycznych [1].

Zgodnie $\mathrm{z}$ powyższym mamy ( $\mathrm{w}$ kolejności od najbardziej istotnych) [1]:

- kąt $\boldsymbol{\theta}$ nachylenia lica spoiny względem materiału rodzimego (MR)

- promień $\rho$ przejścia lica spoiny do MR

- grubość t łączonych elementów

- grubość r' niezgodności spawalniczej typu podtopienie

- kąty $\phi$ ukosowania rowka spawalniczego. 


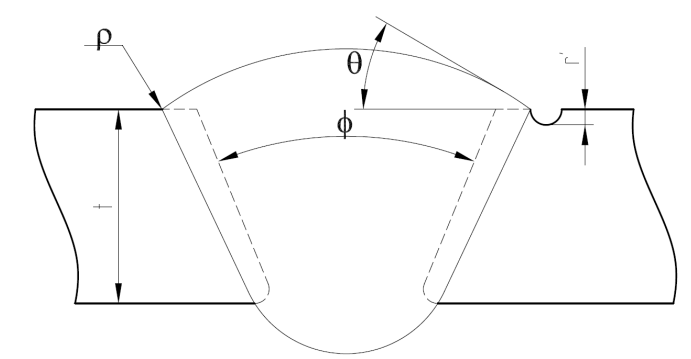

Rys. 6 Model jednostronnego połączenia doczołowego zastosowany w badaniach [1]

Oprócz powyższych czynników wpływających na zmianę parametrów wytrzymałości zmęczeniowej złącza spawanego istnieją jeszcze dwa: naprężenia powstające po spawaniu oraz niezgodności spawalnicze.

Oddziaływanie naprężeń spawalniczych na właściwości konstrukcji wskazuje, że w wielu przypadkach usunięcie jest korzystne, a często konieczne. Powstałe w czasie spawania zmiany właściwości materiału w SWC można częściowo lub całkowicie usunąć za pomocą odprężania. Przy podejmowaniu decyzji o odprężaniu powinno się wziąć pod uwagę następujące czynniki [3]:

- stopień ważności konstrukcji pod względem zagrożenia w przypadku awarii

- możliwość powstania pęknięć kruchych, zmęczeniowych lub korozji wyrobu z naprężeniami

- konieczność uzyskania wymaganej dokładności geometrii podczas obróbki mechanicznej lub zachowania jej w czasie eksploatacji konstrukcji

- możliwość zmian fizycznych i mechanicznych metalu na skutek odprężania cieplnego

- względy ekonomiczne i organizacyjne.

Najbardziej efektywną metodą odprężania jest wyżarzanie odprężające w piecach, które umożliwia stosunkowo precyzyjne przeprowadzenie procesu z gradientem temperatury i zapewnieniem niskiego gradientu temperatury na grubości elementu. Ograniczeniem są na ogół wymiary pieca i dlatego wielkie konstrukcje, np. rurociagi, zbiorniki wyżarzane są miejscowo.

Parametrami odprężania cieplnego są [3]:

- temperatura pieca

- prędkość podnoszenia temperatury wyrobu w czasie nagrzewania

- temperatura i czas wyżarzania

- szybkość chłodzenia

- temperatura wyrobu wyjmowanego z pieca.

Typowy cykl wyżarzania odprężającego przedstawiono na rys. 7.

Kolejnym sposobem usunięcia naprężeń spawalniczych powstałych w złączu po spawaniu jest zabieg odprężania wibracyjnego.

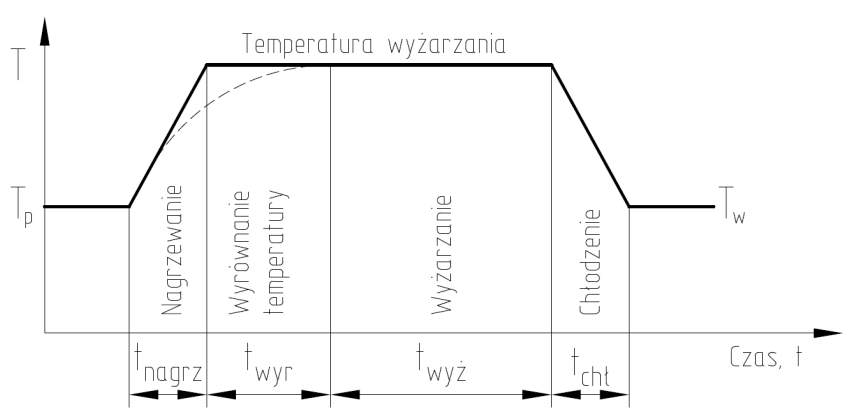

Rys. 7 Typowy prosty cykl wyżarzania odprężającego [3] $T_{p}$ - temperatura początkowa pieca,

$\mathrm{T}_{\mathrm{w}}$ - temperatura pieca w chwili wyjęcia wyrobu

Zabieg ten pozwala na uzyskanie stabilizacji wymiarowej badanego elementu oraz wpływa na podwyższenie trwałości eksploatacyjnej. Naprężenia resztkowe w spawanych elementach pojazdów szynowych są nieodłącznie związane z przemianami fazowymi w procesach spawania. Występują także przy obróbce mechanicznej. Ich występowanie wpływa negatywnie na stabilność wymiarową konstrukcji, powodując w długim czasie jej odkształcenia (odkształcenia zwłoczne) a także zwiększając podatność na pękanie i korozję naprężeniową. Miejsca koncentracji tych naprężeń stanowią karby zmniejszające wytrzymałość zmęczeniową [2].

Dlatego też istotą odprężania wibracyjnego jest doprowadzenie obrabianego elementu do odkształceń dynamicznych. Stosuje się w tym celu zabieg zwany odprężaniem wibracyjnym rezonansowym, polegający na doprowadzaniu elementu do drgań rezonansowych, a więc takich, w których częstotliwość wibratora zgodna jest z częstotliwością drgań własnych elementu [2].

\section{TECHNIKI SPAWANIA METALI [9] 4.1. Spawanie MIG/MAG}

W procesie spawania MIG/MAG (rys. 8) stapiająca się metalowa elektroda stanowi zarazem dodatek spawalniczy i nośnik łuku spawalniczego. Za pośrednictwem dwóch lub czterech rolek napędowych drut spawalniczy jest dostarczany w sposób ciagły do palnika spawalniczego, gdzie w tzw. końcówce prądowej następuje przejście prądu. Wolny wylot drutu jest otoczony współśrodkowo przez dyszę gazowa. Wypływający gaz ochronny zapobiega reakcji chemicznej gorącej powierzchni elementu $\mathrm{z}$ powietrzem $\mathrm{z}$ otoczenia. Umożliwia to zachowanie wytrzymałości i ciągliwości stopiwa. Jako gaz ochronny stosowane sa zarówno gazy obojętne, jak również aktywne. Oprócz właściwości łuku spawalniczego oraz wydajności stapiania, gaz ochronny ma również wpływ na przejście materiału oraz kształt spoiny. Jako gazy obojętne stosowane sa przede wszystkim gazy szlachetne, jak argon $\mathrm{i}$ hel, oraz ich mieszanki. Z pewnymi ograniczeniami jako 
gaz aktywny do spawania stali niestopowych lub niskostopowych nadaje się nawet sam dwutlenek węgla. Jako alternatywę dla gazów ochronnych stosuje się druty rdzeniowe $\mathrm{z}$ otuliną, która $\mathrm{w}$ łuku spawalniczym paruje, wytwarzając $\mathrm{w}$ ten sposób również atmosferę gazu ochronnego.

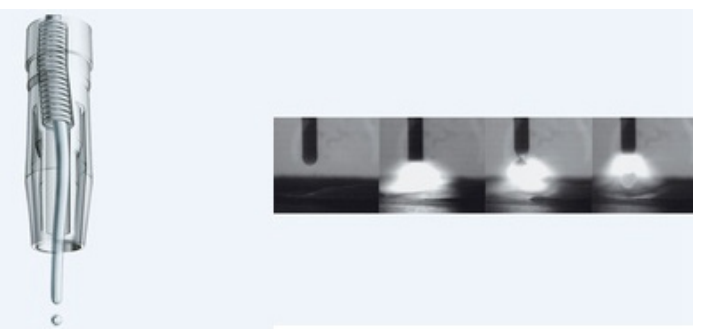

Rys. 8 Spawanie metodą MIG/MAG [9]

Źródło prądu spawalniczego działa z prądem stałym, przy czym potencjał drutu spawalniczego to biegun dodatni. Typowe, przełączane skokowo źródła prądu spawalniczego wyposażone są $\mathrm{w}$ transformator o ilości przełączanych stopni wystarczającej do uzyskania żądanego prąqu spawalniczego. Za transformatorem podłączony jest prostownik, który $\mathrm{z}$ prądu przemiennego wytwarza wyprostowany prąd spawalniczy. Regulowana cewka dławikowa wygładza niepożądane wierzchołki natężenia prądu i redukuje w ten sposób skłonność do powstawania rozprysków podczas spawania.

\subsection{Spawanie TIG}

Głównym elementem palnika TIG (rys. 9) jest nietopliwa, odporna na temperaturę elektroda wolframowa. Wytwarzany przy jej udziale tuk spawalniczy rozgrzewa i upłynnia materiał. Drut spawalniczy jest doprowadzany w razie potrzeby ręcznie lub za pomocą podajnika. W wielu przypadkach niewielka szczelina spawana nie wymaga $\mathrm{w}$ ogóle zastosowania materiału dodatkowego. Zajarzenie łuku spawalniczego odbywa się zwykle bez zetknięcia elektrody wolframowej z elementem. Służy do tego źródło wysokiego napięcia, włączane przejściowo na czas zajarzenia. Spawanie przebiega w przypadku większej części metali z zastosowaniem prądu stałego. Jedynie aluminium spawane jest przy użyciu prądu przemiennego. Elektrodę wolframową otacza dysza doprowadzająca gaz ochronny. Wypływający strumień gazu chroni rozgrzany materiał przed reakcjami chemicznymi $\mathrm{z}$ otaczającym powietrzem i zapewnia $\mathrm{w}$ ten sposób oczekiwaną wytrzymałość i ciągliwość stopiwa. Jako gazy ochronne stosowane są gazy szlachetne: argon, hel oraz ich mieszanki. Wszystkie te gazy są obojętne. Najczęściej stosowanym w spawaniu TIG gazem ochronnym jest argon. Hel z kolei umożliwia bardzo szerokie i głębokie wtopienie, dzięki swemu przewodnictwu cieplnemu, wyższemu dziewięciokrotnie, niż przewodnictwo argonu. Ponadto do spawania stali austenitycznych stosowany jest również wodór, przy czym jego ilość to $2 \%$ do $5 \%$, zaś resztę mieszaniny stanowi argon. Przewodnictwo cieplne wodoru jest nawet jedenastokrotnie wyższe, niż argonu, dzięki czemu można osiągnąć bardzo głębokie wtopienie i nadzwyczaj efektywne odgazowanie.

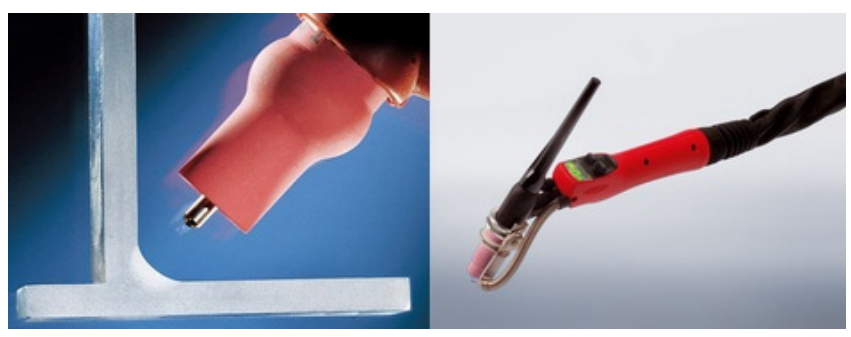

Rys. 9 Spawanie metodą TIG [9]

Niezależnie od długości łuku spawalniczego, idealne źródło prądu spawalniczego TIG wytwarza prawie stały prąd wyjściowy. Ponadto niezbędna jest płynna regulacja prąqu dla wszystkich grubości blach, w związku z czym typowe, tyrystorowe źródła prądu spawalniczego, wyposażone są w prostownik, podłączony za transformatorem spawalniczym.

\subsection{Spawanie Time i TimeTwin}

W przeciwieństwie do typowego spawania MIG/MAG, proces TIME (rys. 10) charakteryzuje dłuższy wolny wylot drutu w palniku spawalniczym, jak również wyższą prędkość drutu oraz modyfikowane gazy ochronne.

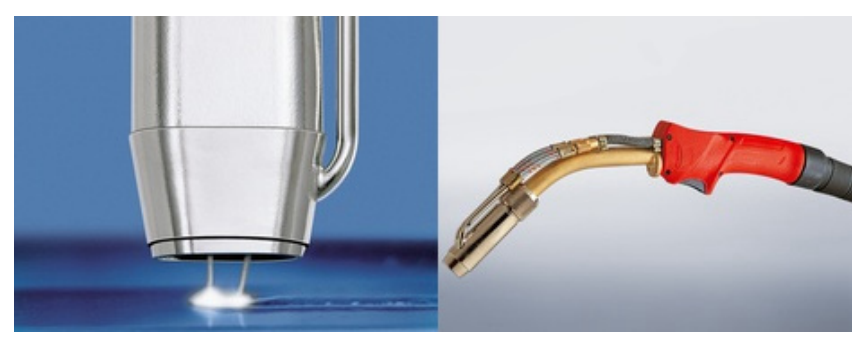

Rys. 10 Spawanie metodą Time i TimeTwin [9]

Metoda TIME o wysokiej wydajności nadaje się zarówno do stosowania ręcznego, zmechanizowanego, jak też zautomatyzowanego. O efektywnym zastosowaniu decyduje w równym stopniu wydajna technologia źródła prądu spawalniczego, jak też elektrody o dobrych własnościach podawania oraz dostosowane do jednostkowych zastosowań gazy ochronne. W najbardziej wydajnym wariancie metody TIME stosowane są dwa druty, które stapiają się równocześnie we wspólnym jeziorku spawalniczym. W przypadku tzw. metody TimeTwin końcówki prądowe specjalnego palnika spawalniczego są od siebie odizolowane, dzięki czemu transfer materiału odbywa się w przypadku każdego drutu elektrodowego z regulacją selektywną. Dzięki temu można osiagnąć prędkość spawania dwu- lub trzykrotnie wyższą $\mathrm{W}$ stosunku do spawania MIG/MAG, przy najwyższej możliwej jakości prawie 
całkowitej eliminacji rozprysków. Jako gaz ochronny stosowane są gazy obojętne $\mathrm{z}$ domieszką gazu aktywnego. Zazwyczaj jest to mieszanina gazów przeważającą ilością argonu, jak również domieszki helu, dwutlenku weggla i tlenu. W wielu przypadkach hel przyczynia się znacznie do przyspieszenia prędkości spawania. Przyczyną tego jest $z$ jednej strony bardzo gorący tuk spawalniczy TIME, $z$ drugiej natomiast wysokie przewodnictwo cieplne helu, który przyczynia się również do optymalnego związania ścianek spoiny. Optymalna zawartość dwutlenku węgla i tlenu zależy również od zastosowania.

Technologia źródeł prądu spawalniczego jest zasadniczo taka sama, jak w przypadku zastosowań MIG/MAG, podobnie jak podajnik drutu i palniki spawalnicze. Ręczne palniki spawalnicze TIME są często wyposażone w regulowaną końcówkę prądową do regulacji wolnego wylotu drutu oraz dwuobiegowy system chłodzenia. Cechą szczególną procesu spawania TimeTwin jest oddzielony potencjał spawania, $z$ własnym źródłem prądu spawalniczego dla każdego z obydwu drutów spawalniczych. Jednostka synchronizująca w źródłach prądu spawalniczego synchronizuje przejście materiału na obydwu drutach spawalniczych w tym samym czasie. Zarówno przesuw drutu, jak też przebieg prądu spawalniczego odbywa się jednakże indywidualnie dla każdego łuku spawalniczego. Zawartość helu w gazie ochronnym powoduje głębsze wtopienie i nadaje spoinom wysoką wytrzymałość dynamiczną. Wskaźnikiem dobrych właściwości spawania są czyste powierzchnie spoin, równe przejścia spoin, jak też niewielka ilość rozprysków. Nie ma potrzeby wykonywania obróbki dodatkowej.

$\mathrm{W}$ przeciwieństwie do spawania TIME z jednym drutem, spawanie TimeTwin ogranicza się, przy zastosowaniu dwóch drutów elektrodowych, do zastosowań zmechanizowanych i zautomatyzowanych. W stosunku do metody z zastosowaniem jednego drutu, metoda dwudrutowa odznacza się lepszą kontrolą jeziorka spawalniczego. Możliwe jest dzięki temu znacznie wyższe oddawanie energii, co wpływa na wzrost prędkości spawania. Zaletę stanowi także przesunięcie w czasie aktywności drugiego łuku spawalniczego, co daje efekt wydłużenia czasu odgazowania, dzięki czemu powstaje znacznie mniej porów.

\subsection{Spawanie CMT}

Metoda CMT (rys. 11) jest efektem ustawicznego dostosowywania procesu spawania $\mathrm{MIG} / \mathrm{MAG}$ do potrzeb łączenia stali $\mathrm{z}$ aluminium. CMT zapewnia kontrolowane, prawie bezprądowe przejście materiału. Aluminiowy materiał podstawowy topi się razem $\mathrm{z}$ aluminiowym spoiwem a ciekły metal pokrywa ocynkowany materiał stalowy. W krótkich odsteppach czasu drut spawalniczy porusza się w kierunku przeciwnym do kierunku podawania. To precyzyjnie zdefiniowane cofanie drutu wpływa na kontrolowane odrywanie kropli oraz czyste, bezrozpryskowe przejście materiału. Ruch drutu odbywa się $\mathrm{z}$ dużą częstotliwością $\mathrm{i}$ wymaga reagującego szybko, bezprzekładniowego napędu podawania drutu bezpośrednio przy palniku spawalniczym. Oczywiście główny napęd podajnika drutu nie może sprostać tym wymogom ruchu. Przewód podający drut wyposażony został w związku $\mathrm{z}$ tym w tzw. bufor drutu, który kompensuje dodatkowy ruch drutu w jedną i w drugą stronę.

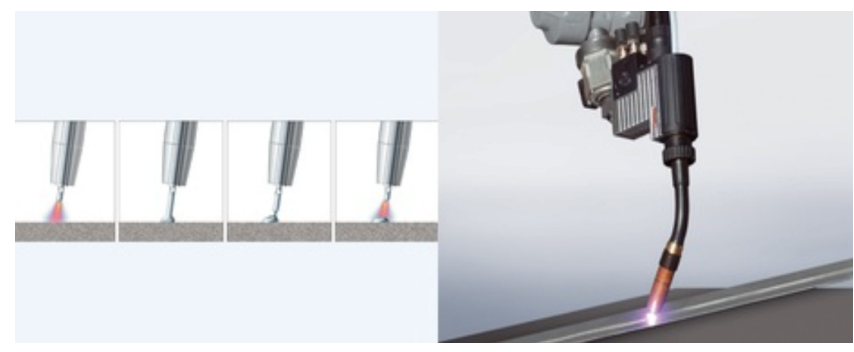

Rys. 11 Spawanie metodą CMT [9]

Spawanie CMT odbywa się wyłącznie z zastosowaniem całkowicie cyfrowych, inwerterowych źródeł prądu spawalniczego. System spawalniczy jest zasadniczo zgodny sprzętowo z systemem MIG/MAG na najnowszym poziomie technicznym, jednakże $\mathrm{z}$ uwzględnieniem kilku specyficznych wymogów. Warto wspomnieć przy tym zwłaszcza o napędzie drutu, charakteryzującym się wysoką dynamiką, umieszczonym bezpośrednio przy palniku spawalniczym. Gdy źródło prądu spawalniczego rozpozna zwarcie, rozpoczyna się ruch powrotny drutu spawalniczego, przy równocześnie zmniejszonym prądzie spawalniczym. Odrywa się dokładnie jedna kropla, bez najmniejszych nawet rozprysków. Następnie drut spawalniczy posuwa się ponownie do przodu, a cykl rozpoczyna się od nowa. Wysoka częstotliwość i najwyższa precyzja to warunek podstawowy całkowicie kontrolowanego przejścia materiału. Napęd drutu przy palniku spawalniczym zaprojektowany jest tylko odpowiednio do prędkości, nie jest natomiast przystosowany do dużych sił ciagnących. Dlatego też podawanie drutu odbywa się za pośrednictwem silniejszego, głównego napędu drutu, charakteryzującego się ze względów konstrukcyjnych większą bezwładnością. Na przewodzie podającym drut umieszczony jest bufor. Jest to element kompensujący posuwisto zwrotny ruch drutu wysokiej częstotliwości $\mathrm{w}$ stosunku do liniowego podawania drutu.

\subsection{Spawanie LaserHybrid}

Wysoka prędkość spawania przy dużej głębokości wtopienia i dobrych właściwościach wypełniania szczelin stanowi już sama w sobie wyzwanie w dziedzinie spawalnictwa. Jeśli dodatkowo mają być spełnione najwyższe oczekiwania co do wyniku spawania 
oraz szerokiego spektrum spawanych materiałów i grubości blach, niezbędna jest skoncentrowana dawka techniki i wiedzy. Zwłaszcza w przypadku aluminium wymienione wyżej wymogi stanowią dla techniki połączeń wyzwanie, które wymaga najlepszych cech wielu metod spawania równocześnie.

W rzeczywistości powiodło się połączenie zalet całkowicie cyfrowego procesu spawania MIG/MAG z zaletami spawania laserowego w postaci jednej metody. Metodę tę, nazywaną LaserHybrid (rys. 12), cechuje $\mathrm{z}$ jednej strony dobre wypełnianie szczelin i proste przygotowywanie spoin metody MIG/MAG, $z$ drugiej zaś posiada ona zalety spawania laserowego, jak np. skoncentrowane odprowadzanie ciepła, dużą głębokość wtopienia i prędkość. Gdy promień lasera trafi na powierzchnię elementu, rozgrzewa odpowiedni obszar do temperatury parowania. W efekcie tego powstaje siegający głęboko słup pary, z oczekiwanym efektem głębokiego, wąskiego wtopienia. $\mathrm{W}$ procesie spawania LaserHybrid zapotrzebowanie na drogą energię lasera ogranicza się prawie wyłącznie do tego tzw. efektu spawania głębokiego, który umożliwia również łączenie grubszych blach. Pozostałe zapotrzebowanie energii pokrywa tani proces MIG/MAG, który wraz z zastosowaniem elektrody topliwej umożliwia lepsze wypełnianie szczelin. Ponieważ oba te procesy częściowe koncentrują swą energię na tej samej strefie procesu, znacznie powiększają głębokość spawania i prędkość w stosunku do metod pojedynczych.

Sercem systemu spawalniczego LaserHybrid jest niewielka głowica LaserHybrid ze zintegrowanym palnikiem spawalniczym MIG/MAG oraz zamontowanym układem optycznym lasera. Podłączenie głowicy LaserHybrid do typowego robota przemysłowego odbywa się za pomocą uchwytu robota. Umożliwia on elastyczne umieszczenie głowicy LaserHybrid, dzięki czemu dostępne są również fragmenty elementu spawanego o utrudnionym dostępie. Drut spawalniczy można ustawić we wszystkich kierunkach w stosunku do promienia lasera, co zapewnia efekt dokładnego dostosowania procesu łączenia do zadań połączeń.
W odniesieniu do długości spoiny, zużycie gazu ochronnego ogranicza się nawet tylko do jednej osiemnastej. Niewielkie zapotrzebowanie ciepła przez metodę MIG/MAG oznacza również, że stapia się znacznie mniej drutu spawalniczego. Przewyższenie spoiny znacznie się zmniejsza i powstaje oczekiwana powierzchnia spoiny o znacznie mniejszym wybrzuszeniu. Zwłaszcza w przypadku spoin pachwinowych, ze względu na większą głębokość wtopienia, uzyskuje się większą wytrzymałość, niż na przykład podczas spawania laserowego bez dodatkowego procesu MIG/MAG. Alternatywnie można również zmniejszyć dzięki temu objętość spoin. Obydwa efekty, mniejsze przewyższenie spoiny oraz zoptymalizowana głębokość wtopienia, mogą przy tym przyczynić się do znacznej redukcji zużycia drutu.

\section{ZAKOŃCZENIE}

Wymagania stawiane współczesnym konstrukcjom spawanym w pojazdach szynowych są coraz ostrzejsze. $\mathrm{Z}$ jednej strony wymaga się większego bezpieczeństwa użytkowania i ograniczenia masy komponentów a z drugiej obniżenia kosztów produkcji i wytwarzania oraz zmniejszenia czasu do uzyskania gotowego produktu. Wymusza to stosowanie coraz lepszych materiałów oraz coraz nowszych technologii projektowania i wytwarzania. Na etapie projektowania stosuje się coraz bardziej zaawansowane metody obliczeniowe pozwalające na odwzorowanie warunków eksploatacyjnych pojazdu i tym samym na optymalizację konstrukcji pod względem wymiarowym. Dodatkowo współcześnie, jako materiały konstrukcyjne, stosuje się stale o wysokich parametrach wytrzymałościowych pozwalające na utrzymanie wysokich współczynników bezpieczeństwa przy zachowaniu odpowiednich parametrów geometrycznych konstrukcji (coraz mniejsze ryzyko „przewymiarowania” konstrukcji). Również techniki spawania komponentów coraz częściej pozwalają na uzyskanie konstrukcji stabilnej wymiarowo o wymaganych parametrach mechanicznych (pod względem wytrzymałości zmęczeniowej) bez konieczności przeprowadzania często skomplikowanych operacji pospawalniczych (jak odprężanie, wyżarzanie itp.)

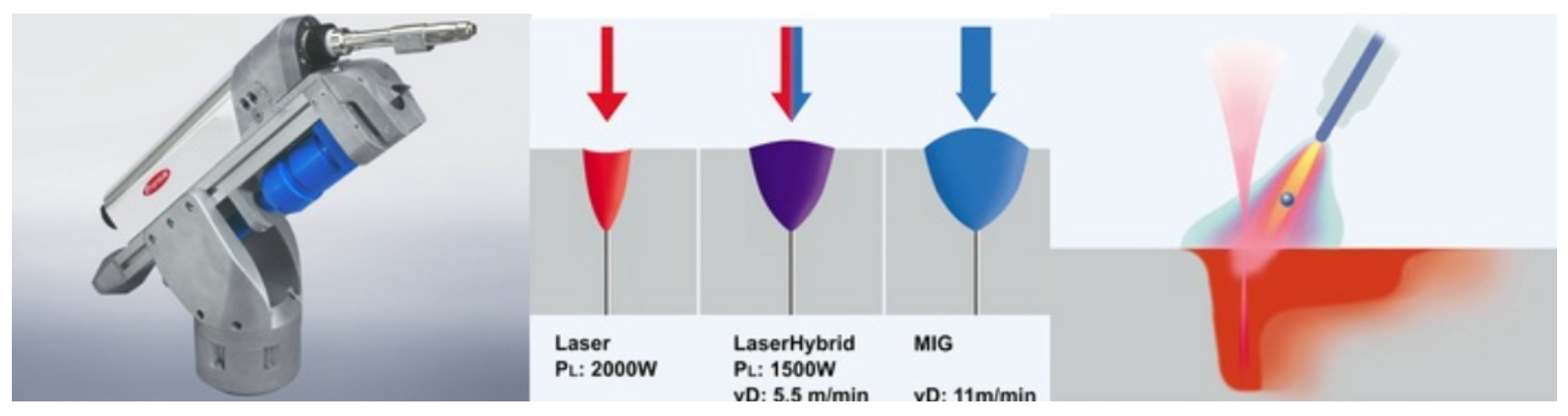

Rys. 12 Spawanie metodą LaserHybrid [9] 


\section{LITERATURA}

[1] Eukasik T., Szubyrt M. Wytrzymatość zmęczeniowa konstrukcji spawanych - metody nowego podejścia. Seminarium: Zagadnienia wytrzymatości zmęczeniowej konstrukcji spawanych - projektowanie, wykonawstwo, badania. Instytut Spawalnictwa w Gliwicach. Grudzień 2007

[2] Sobaś M., Antkowiak T., Kalinowski D. Wózek lokomotywy 111E. Pojazdy szynowe 4/2013

[3] Ferenc K. Spawalnictwo. Wydawnictwo Naukowo Techniczne. Warszawa 2013.

[4] EN 15085-1 Kolejnictwo - Spawanie pojazdów szynowych i ich części sktadowych-Część 1: Postanowienia ogólne

[5] EN 15085-2 Kolejnictwo - Spawanie pojazdów szynowych i ich części skladowych -Część 2: Wymagania jakości i certyfikacja zaktadów spawalniczych

[6] EN 15085-3 Kolejnictwo - Spawanie pojazdów szynowych i ich czesści składowych - Część 3: Wymagania konstrukcyjne

[7] EN 15085-4 Kolejnictwo - Spawanie pojazdów szynowych i ich części składowych - Część 4: Wymagania produkcyjne

[8] EN 15085-5 Kolejnictwo - Spawanie pojazdów szynowych i ich części sktadowych - Część 5:Kontrola, badania i dokumentacja

[9] Strona internetowa: www.fronius.com (dostęp: 19.02.2014) 